\title{
Pengaruh Model Problem Solving terhadap Kemampuan Penalaran dan Hasil Belajar Fisika di Kelas XI MAN 1 Kepahiang
}

\author{
Krisma Ayu Sutrisno, Eko Swistoro, Rosane Medriati \\ Program Studi Pendidikan Fisika Jurusan MIPA \\ Fakultas Keguruan dan Ilmu Pendidikan Universitas Bengkulu \\ Jalan Raya Kandang Limun Bengkulu \\ E-mail: krismaayus@gmail.com
}

\begin{abstract}
ABSTRAK
Penelitian ini bertujuan untuk mengetahui pengaruh model Problem Solving terhadap kemampuan penalaran dan hasil belajar fisika fluida statis di kelas XI MAN 1 Kepahiang. Jenis penelitian adalah quasi eksperiment dan jenis disain yang digunakan adalah nonequivalent control design dengan dua kelas sampel yakni 1 kelas eksperimen dan 1 kelas kontrol. Pengukuran menggunakan pretest dan posttest. Teknik analisis yang digunakan adalah statistik inferensial dan dilanjutkan dengan uji-t dua sampel independen. Hasil penelitian menyimpulkan bahwa ada pengaruh model Problem Solving terhadap kemampuan penalaran di MAN 1 Kepahiang, yakni $t_{\text {hitung }} 2,4>t_{\text {tabel }} 2,02$, dan terdapat pengaruh signifikan model Problem Solving terhadap hasil belajar fisika di MAN 1 Kepahiang yang ditunjukkan dengan $t_{\text {hitung }} 4,41>t_{\text {tabel }} 2,02$. Dapat disimpulkan bahwa terdapat pengaruh yang signifikan model Problem Solving terhadap kemampuan penalaran dan hasil belajar fisika fluida statis di kelas XI MAN 1 Kepahiang.
\end{abstract}

Kata Kunci : Problem Solving, Kemampuan Penalaran, Hasil Belajar

\begin{abstract}
This study aims to determine the effect of the Problem Solving model on reasoning ability and learning outcomes of static fluid physics in class XI MAN 1 Kepahiang. This type of research was quasi experiment and the type of design used is nonequivalent control design with two sample classes namely 1 experimental class and 1 control class. Measurement using pretest and posttest. The analysis technique used was inferential statistics and continued with two independent sample t-tests. The results concluded that there was an effect of the Problem Solving model on reasoning ability in MAN 1 Kepahiang, namely tcount 2.4>t table 2.02, and there was a significant influence on the Problem Solving model on physics learning outcomes in MAN 1 Kepahiang as indicated by tcount $4.41>$ table 2.02. It can be concluded that there is a significant influence on the Problem Solving model on reasoning ability and learning outcomes of static fluid physics in class XI MAN 1 Kepahiang.
\end{abstract}

Keywords : Problem Solving Model, Reasoning Ability, Learning Outcomes.

\section{PENDAHULUAN}

Dalam standar isi yang diterbitkan oleh Permendikbud, pembelajaran fisika bertujuan agar peserta didik memiliki kemampuan untuk mengembangkan bernalar dalam berpikir analisis induktif dan deduktif menggunakan konsep dan prinsip fisika menjelaskan berbagai peristiwa alam dan menyelesaikan masalah baik secara kualitatif maupun kuantitatif. Pembelajaran fisika diharapkan dapat memberikan penataan nalar, berpikir kritis, pembentukan sikap siswa, serta kemampuan penerapannya dalam kehidupan sehari-hari maupun dalam mempelajari berbagai ilmu pengetahuan [1]. Sekarang ini pembelajaran fisika yang dilaksanakan masih banyak yang menggunakan pembelajaran konvensional yang hanya menekankan pada tuntutan kurikulum sehingga dalam prakteknya siswa bersifat pasif dalam proses pembelajaran. Keterlibatan siswa cendrung terminimalisasi sehingga mengakibatkan kemampuan penalaran siswa kurang dikembangkan dengan baik [2].

Kemampuan penalaran yang tertuang dalam permendiknas No.22 tahun 2006 tentang standar isi (SI) merupakan salah satu dari kompetensi yang harus dimiliki oleh peserta didik [3]. Cf Giere dan Soekardjo menjelaskan bahwa penalaran merupakan kegiatan, proses, atau aktivitas berpikir 
untuk menarik suatu kesimpulan atau membuat suatu pernyataan baru berdasar pada beberapa pernyataan yang diketahui benar ataupun yang dianggap benar, yang disebut premis [4]. Menurut Yudhi Munadi (2008) yang membedakan pelajar dengan orang yang bukan pelajar, mahasiswa dengan pemuda yang bukan mahasiswa adalah faktor penalarannya, dan yang membedakan pelajar dengan pelajar lainnya adalah kadar kekuatan penalarannya atau daya nalarnya. Ini ditentukan oleh individual power of reasoning (daya nalar individu) yang merupakan dasar yang paling menentukan dari kemampuan berpikir analitis dan sintesis [5].

Setelah melakukan wawancara dengan guru fisika di MAN 1 Kepahiang, diperoleh bahwa: 1) Proses pembelajaran lebih sering menggunakan metode ceramah dan latihan soal yang didominasi oleh guru, 2) Kurangnya kemampuan penalaran siswa, hal ini terlihat saat pembelajaran fisika rendahnya kemampuan siswa memahami materi, dan 3) Hasil belajar siswa tidak lebih dari 50\% yang mencapai kriteria ketuntasan minimal. Dari hasil wawancara maka diperlukan model pembelajaran yang dapat membantu siswa agar dapat meningkatkan kemampuan penalaran dan hasil belajar.

Model yang relevan diperlukan untuk mengoptimalkan dan meningkatkan kemampuan penalaran siswa. Salah satu cara memperbaiki rendahnya penalaran peserta didik adalah dengan cara mengubah model pembelajaran yang biasa digunakan dengan model pembelajaran yang lebih mendukung aktivitas siswa dalam memahami suatu materi dan lebih menekankan siswa berperan aktif dalam pembelajaran sehingga dapat meningkatkan penalaran siswa [2].

Dari banyaknya model dalam pembelajaran, salah satu yang dapat digunakan agar pembelajaran dapat berlangsung secara efektif adalah dengan model Problem Solving. Menurut Krulik \& Rudnick (1996) Problem Solving adalah upaya individu atau kelompok untuk menemukan jawaban berdasarkan pengetahuan, pemahaman, keterampilan yang dimiliki sebelumnya dalam rangka memenuhi tuntutan yang tak lumrah tersebut [6].

Model pembelajaran Problem Solving sudah banyak diteliti dan terbukti dapat meningkatkan hasil belajar siswa. Hasil penelitian Festus \& Ekpete (2012), Taasoobshirazi \& Glynn (2009), Karatas \& Baki (2013), Yaqin \& Pramunkuntoro (2013), Warimun (2012), menyatakan bahwa penerapan model pembelajaran Problem Solving dapat meningkatkan hasil belajar siswa [7].

Model Problem Solving dapat melatih dan membiasakan para peserta didik menjadi lebih menghayati kehidupan sehari-hari. Aktivitas Problem Solving diawali dengan konfrontasi dan berakhir apabila sebuah jawaban telah diperoleh sesuai dengan kondisi masalah. Kemampuan pemecahan masalah dapat diwujudkan melalui kemampuan penalaran [6].

Berdasarkan latar belakang, maka rumusan masalah pada penelitian ini yaitu: 1) Apakah terdapat pengaruh model Problem Solving terhadap kemampuan penalaran siswa MAN 1 Kepahiang? 2) Apakah terdapat pengaruh model Problem Solving terhadap hasil belajar siswa MAN 1 Kepahiang? Penelitian ini bertujuan Untuk menentukan pengaruh model Problem Solving terhadap kemampuan penalaran siswa MAN 1 Kepahiang dan Untuk menentukan pengaruh model Problem Solving terhadap hasil belajar siswa MAN 1 Kepahiang.

\section{METODE PENELITIAN}

Penelitian ini merupakan penelitian dalam bentuk experiment research (penelitian eksperimen). Penelitian ini menggunakan 2 kelas yang dibagi menjadi kelas eksperimen dan kelas kontrol. Kelas eksperimen mengikuti pembelajaran menggunakan model Problem Solving dengan desain penelitian non-equivalent control group design dapat dilihat pada tabel 2.1, sedangkan kelas kontrol menggunakan pembelajaran konvensional yaitu model pembelajaran yang biasa dipakai guru di sekolah (pembelajaran langsung). Penelitian ini dilakukan di kelas XI IPA MAN 1 Kepahiang pada semester genap tahun ajaran 2017/2018 yaitu pada 23 Februari - 23 Mei 2018.

Pengambilan sampel pada penelitian ini dilakukan dengan teknik purpossive sampling. Pertimbangan yang diambil yaitu berdasarkan tingkat kemampuan rata-rata kedua kelas dapat dikategorikan sama [8]. Berdasarkan hal di atas, diperoleh sampel penelitian yaitu kelas XI IPA 1 sebagai kelas eksperimen dan kelas XI IPA 2 sebagai kelas kontrol. 
Tabel 1. Desain Penelitian Non-equivalent control group design

\begin{tabular}{cccc}
\hline Kelas & Pretest & Perlakuan & Posttest \\
\hline Kelas eksperimen & $\mathrm{O}_{1}$ & $\mathrm{X}$ & $\mathrm{O}_{2}$ \\
Kelas kontrol & $\mathrm{O}_{3}$ & - & $\mathrm{O}_{4}$ \\
\hline
\end{tabular}

Teknik pengumpulan data dalam penelitian berupa soal tes yang diberikan sebanyak dua kali yaitu pada saat awal pembelajaran (pretest) dan pada akhir pembelajaran (posttest). Tes adalah alat atau prosedur yang dipergunakan dalam rangka pengukuran dan penilaian [9]. Pada kelas ekperimen diberi perlakuan dengan model Problem Solving dan pada kelas kontrol menggunakan metode konvensional. Analisis Data penelitian sebagai berikut.

Menghitung rata-rata $(\bar{x})$ mengunakan rumus:

$$
\bar{x}=\frac{\sum X_{i}}{n}
$$

Perhitungan Standar Deviasi (s) dapat dihitung dengan rumus:

$$
S=\frac{\sqrt{n \sum x i^{2}-\left(\sum x i\right)^{2}}}{n(n-1)}
$$

Untuk analisis inferensial yang digunakan adalah uji normalitas yaitu uji chi kuadrat dan uji homogenitas dengan dua varians. Setelah itu dilakukan uji t-test dua sample independent dengan keduanya homogen sehingga rumus t-test yang jumlahnya $\mathrm{n}_{1} \neq \mathrm{n}_{2}$. Rumus t-test yang digunakan yaitu uji t polled varian dengan derajat kebebasan $(\mathrm{dk})=\mathrm{n}_{1}+\mathrm{n}_{2}-2$ sebagai berikut:

$$
\mathrm{t}=\frac{\bar{X}_{1}-\bar{X}_{2}}{\sqrt{\frac{\left(n_{1}-1\right) S_{1}^{2}+\left(\left(n_{2}-1\right) S_{2}^{2}\right.}{n_{1}+n_{2}-2} \times \frac{1}{n_{1}}+\frac{1}{n_{2}}}}
$$

Dimana $\bar{X}_{1}$ merupakan rata-rata nilai kelas eksperimen, $\bar{X}_{2}$ merupakan rata-rata nilai kelas kontrol, $\mathrm{n}_{1}$ adalah banyaknya jumlah siswakelas eksperimen, $\mathrm{n}_{2}$ adalah banyaknya jumlah siswa kelas kontrol, $S_{1}^{2}$ adalah varians nilai kelas eksperimen, $S_{2}^{2}$ adalah varians nilai kelas kontrol [10].

\section{HASIL DAN PEMBAHASAN}

3.1 Deskripsi data hasil penelitian

3.1.1 Kemampuan Penalaran

Kemampuan penalaran sebelum diberi perlakuan diberikan pretest pada setiap kelas sebanyak tiga kali pada tiga kali pertemuan. Dari ketiga hasil pretest tersebut akan diperoleh rata-rata. Dimana pada kelas eksperimen didapat skor rata-rata kemampuan penalaran untuk pretest 38,82 dan standar deviasinya sebesar 7,92 untuk skor posttest kemampuan penalaran kelas eksperimen 80,83 dan standar deviasinya 7,88. Sedangkan untuk kelas kontrol rata-rata skor pretest kemampuan penalaran yaitu 30,16 dan standar deviasinya 5,84 sedangkan untuk skor posttest kemampuan penalaran kelas kontrol 73,97 dan standar deviasinya 5,35.

\subsubsection{Hasil Belajar Siswa}

Hasil belajar sebelum diberi perlakuan di berikan pretest pada setiap kelas sebanyak tiga kali pada tiga kali pertemuan. Dari ketiga hasil pretest tersebut akan diperoleh rata-rata. Dimana pada kelas eksperimen didapat skor rata-rata hasil belajar untuk pretest 33,33 dengan standar deviasinya sebesar 7,85 untuk skor posttest hasil belajar siswa kelas eksperimen 79,17 dan standar deviasinya 5,6 Sedangkan untuk kelas kontrol rata-rata skor pretest hasil belajar yaitu 30,65 dan standar deviasinya 6,72 sedangkan untuk skor posttest hasil belajar siswa kelas kontrol 70,32 dan standar deviasinya 8,51 .

Rata-rata skor pretest dan posttest kemampuan penalaran maupun hasil belajar siswa di uji normalitasnya menggunakan rumus chi kuadrat dan diuji homogenitasnya menggunakan rumus perbandingan varian terbesar dengan varian terkecil antara kedua kelompok sampel dengan taraf 
signifikansi 95\%. Hasil dari uji normalitas dan homogenitas semua data berdistribusi normal dan homogen maka di lakuakan uji beda dengan uji parametrik (uji t). Hasil uji beda antara pretest dan posttest kemampuan penalaran dan hasil belajar bisa di lihat pada Tabel 3.1.

Tabel 2. Hasil Uji Beda Pretest dan Posttest kemampuan penalaran dan Hasil Belajar Kelas Eksperimen dan Kelas Kontrol

\begin{tabular}{|c|c|c|c|c|c|c|}
\hline \multicolumn{7}{|c|}{ Kemampuan Penalaran } \\
\hline Hasil & Kelas & $\mathbf{N}$ & $\begin{array}{l}\text { Rata- } \\
\text { rata }\end{array}$ & $\mathbf{t}_{\text {hitung }}$ & $\begin{array}{c}\mathbf{t}_{\text {tabel }} \\
(\mathrm{dk}=43)\end{array}$ & Kesimpulan \\
\hline \multirow[t]{2}{*}{ Pretest } & Eksperimen & 24 & 39 & \multirow[t]{2}{*}{1,55} & \multirow[t]{2}{*}{2,02} & TIDAK \\
\hline & Kontrol & 21 & 35,9 & & & $\begin{array}{l}\text { BERBEDA } \\
\text { SIGNIFIKAN }\end{array}$ \\
\hline \multirow[t]{2}{*}{ Posttest } & Eksperimen & 24 & 79,3 & \multirow[t]{2}{*}{2,4} & \multirow[t]{2}{*}{2,02} & BERBEDA \\
\hline & Kontrol & 21 & 73,7 & & & SIGNIFIKAN \\
\hline \multicolumn{7}{|c|}{ Hasil Belajar } \\
\hline Hasil & Kelas & $\mathbf{N}$ & $\begin{array}{c}\text { Rata- } \\
\text { rata }\end{array}$ & $t_{\text {hitung }}$ & $\begin{array}{c}\mathbf{T}_{\text {tabel }} \\
(\mathbf{d k}=43)\end{array}$ & Kesimpulan \\
\hline \multirow[t]{2}{*}{ Pretest } & Eksperimen & 24 & 32,6 & \multirow[t]{2}{*}{1,08} & \multirow[t]{2}{*}{2,02} & TIDAK \\
\hline & Kontrol & 21 & 31 & & & $\begin{array}{l}\text { BERBEDA } \\
\text { SIGNIFIKAN }\end{array}$ \\
\hline \multirow[t]{2}{*}{ Posttest } & Eksperimen & 24 & 79,2 & \multirow[t]{2}{*}{4,41} & \multirow[t]{2}{*}{2,02} & BERBEDA \\
\hline & Kontrol & 21 & 56,8 & & & SIGNIFIKAN \\
\hline
\end{tabular}

Berdasarkan tabel di atas terlihat bahwa data hasil $\mathrm{t}_{\text {hitung }}$ pretest kelas eksperimen dan kelas kontrol lebih kecil dari $t_{\text {tabel, }}$ hal ini menunjukkan bahwa kemampuan penalaran dan hasil belajar sebelum diberi perlakuan tidak berbeda secara signifikan. Hasil ini menunjukkan bahwa kedua kelas memiliki kemampuan yang sama saat sebelum diberi perlakuan. Dari tabel juga terlihat bahwa

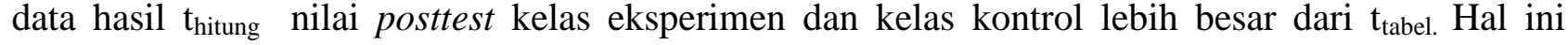
menunjukkan kemampuan penalaran dan hasil belajar kedua kelas setelah diberi perlakuan, berbeda secara signifikan pada taraf signifikan $95 \%$.

3.2 Pembahasan

\subsubsection{Kemampuan Penalaran}

Selama ini pembelajaran fisika yang dilaksanakan masih banyak yang menggunakan pembelajaran konvensional yang hanya menekankan pada tuntutan kurikulum sehingga dalam prakteknya siswa bersifat pasif dalam proses pembelajaran. Keterlibatan siswa cendrung terminimalisasi sehingga mengakibatkan kemampuan penalaran siswa kurang dikembangkan dengan baik [2]. Dengan pembelajaran menggunakan model Problem Solving dapat meningkatkan kemampuan penalaran siswa. Hasil penelitian ini menunjukkan bahwa kemampuan penalaran siswa kelas eksperimen yang diberi pembelajaran model Problem Solving lebih tinggi dibandingkan kelas kontrol dengan menggunakan pembelajaran konvensional. Dengan kemampuan penalaran yang tinggi sehingga berpengaruh pada hasil belajar siswa.

Berdasarkan data rata-rata skor kemampuan penalaran awal belajar siswa antara kelas eksperimen dan kelas kontrol, dilakukannya uji-t sampel independen untuk mengetahui perbedaan skor kedua kelas tersebut menunjukan bahwa tidak terdapat perbedaan secara signifikan pada motivasi awal kedua kelas. Tetapi setelah diberi pembelajaran dengan menggunakan model Problem Solving pada kelas eksperimen skor rata-rata posttest kemampuan penalaran siswa lebih tinggi dibandingkan skor rata-rata posttest kelas kontrol yang menggunakan metode pembelajaran konvensional. Skor rata-rata posttest kemampuan penalaran siswa kelas eksperimen 80,83 sedangkan pada kelas kontrol 75,48. Berdasarkan uji perbedaan rata-rata dengan menggunakan uji-t sampel independen diperoleh $\mathrm{t}_{\text {hitung }}=2,92$ dan $\mathrm{t}_{\text {tabel }}=2,02$ dengan $\mathrm{dk}=43$ pada taraf signifikan $95 \%$, sehingga $t_{\text {hitung }}>t_{\text {tabel }}$ hal ini berarti terdapat perbedaan signifikan antara kelas eksperimen dan kelas kontrol. Dapat disimpulkan bahwa menggunakan model problem solving terdapat pengaruh positif terhadap kemampuan penalaran siswa. Hal ini senada dengan penelitian Ario (2016) dalam 
penelitiannya tentang analisis kemampuan penalaran matematis siswa SMK setelah mengikuti pembelajaran berbasis masalah diperoleh kemampuan penalaran matematis siswa setelah mengikuti pembelajaran berbasis masalah termasuk baik dengan tingkat ketercapaian 77,19\%.

\subsubsection{Hasil Belajar}

Setelah dilakukan pembelajaran dengan model problem solving pada kelas eksperimen, skor rata-rata posttest yang diperoleh mencapai 79,17 . Pada kelas kontrol yang diajarkan dengan menggunkan pembelajaran konvensiaonal, skor rata-rata posttest hanya mencapai 75,48 . Berdasarkan uji perbedaan rata-rata sampel independent menunjukkan bahwa $t_{\text {hitung }}=11,36>\mathrm{t}_{\text {tabel }}=$ 2,02 dengan $\mathrm{dk}=43$ pada taraf signifikan $95 \%$ yang berarti terdapat perbedaan hasil belajar yang signifikan antara kelas eksperimen dan kelas kontrol. Hasil penelitian ini menunjukkan bahwa hasil belajar kelas eksperimen yang diajarkan dengan model problem solving lebih tinggi dibandingkan hasil belajar kelas kontrol yang diajarkan dengan pembelajaran konvensional. Hasil penelitian ini sesuai dengan hasil penelitian yang telah dilakukan oleh Suwardi dkk (2017) yang menunjukkan bahwa terjadi peningkatan hasil belajar fisika peserta didik kelas XI IPA 1 SMAN 1 Parangloe yang diajar melalui pendekatan pembelajaran Problem Solving.

Berdasarkan hasil belajar antara siswa yang diajarkan menggunakan model pembelajaran Problem Solving dengan siswa yang diajarkan menggunakan pembelajaran konvensional dipengaruhi oleh berbagai faktor, antara lain karena model dan metode pembelajaran yang diterapkan. Model pembelajaran Problem Solving yang diterapkan pada kelas eksperimen adalah model pembelajaran dimana siswa dibagi dalam kelompok-kelompok, Setelah siswa dibagi dalam kelompok, setiap kelompok akan diberi tugas menyelesaikan masalah yang telah tersusun dilembar kerja peserta didik. Sebelum memulai kegiatan ini guru menyampaikan tujuan pembelajaran dan motivasi siswa agar terlibat aktif dalam proses pemecahan masalah. Kekuatan proses pembelajaran berbasis masalah terletak pada pemecahan masalah yang berkaitan dengan dunia nyata siswa.

Pada kelas kontrol, motode pembelajaran yang diterapkan adalah pembelajaran konvensional yang terdiri dari kegiatan diskusi dan latihan soal. Pertama guru menyampaikan tujuan pembelajaran dan memberikan apersepsi untuk mempersiapkan dan memotivasi siswa untuk belajar. Selanjutnya, Guru menyajikan informasi atau menjelaskan materi pelajaran secara keseluruhan, kemudian guru memberikan umpan balik dengan cara memberikan soal-soal dan meminta perwakilan kelompok untuk menulis jawaban kedepan, , setelah itu guru memberikan kesempatan untuk latihan lanjutan. Pada kelas kontrol ini kebanyakan siswa mengeluhkan proses pembelajaran, siswa merasa bosan belajar dengan diberi soal-soal dan mendengar ceramah sehingga berdampak pada hasil belajarnya yang jauh dari yang diharapkan.

Hasil penelitian ini terjadi peningkatan kemampuan penalaran dan hasil belajar siswa kelas eksperimen, berbeda dengan peningkatan kemampuan penalaran dan hasil belajar kelas kontrol. Peningkatan kemampuan penalaran dan hasil belajar siswa kelas eksperimen lebih tinggi dibanding dengan peningkatan kemampuan penalaran dan hasil belajar kelas kontrol, dan dengan didukung oleh penelitian-penelitian sebelumnya, maka dapat disimpulkan bahwa pembelajaran dengan model Problem Solving berpengaruh terhadap kemampuan penalaran dan hasil belajar siswa kelas XI IPA di MAN 1 Kepahiang.

\section{SIMPULAN DAN SARAN}

\subsection{Kesimpulan}

Berdasarkan hasil penelitian maka dapat di simpulkan bahwa: 1) Terdapat pengaruh yang signifikan model Problem Solving terhadap kemampuan penalaran siswa di MAN 1 Kepahiang yang ditunjukkan dengan $t_{\text {hitung }} 2,4>t_{\text {tabel }} 2,02$ untuk taraf signifikan 95\% dan 2) Terdapat pengaruh yang signifikan model Problem Solving terhadap hasil belajar siswa di MAN 01 Kepahiang yang ditunjukkan dengan $\mathrm{t}_{\text {hitung }} 4,41>\mathrm{t}_{\text {tabel }} 2,02$ untuk taraf signifikan $95 \%$.

\subsection{Saran}

Berdasarkan kesimpulan penelitian, maka penulis merekomendasikan berupa saran-saran sebagai berikut: 1) Model pembelajaran Problem Solving dapat digunakan guru sebagai salah satu 
alternatif cara untuk meningkatkan hasil belajar siswa. 2) Agar kemampuan penalaran siswa lebih baik, hendaknya guru menggunakan model Problem Solving pada materi lainnya. Dan 3) Bagi peneliti selanjutnya yang tertarik dengan model Problem Solving disarankan untuk mengembangkan penelitiannya lebih luas. Hasil penelitian ini dapat dijadikan acuan untuk melanjutkan penelitian pada materi lainnya.

\section{DAFTAR PUSTAKA}

[1] Peraturan Menteri Pendidikan Nasional Nomor 22 Tahun 2006 Tentang Standar Isi Untuk Satuan Pendidikan Dasar dan Menengah. 2006. Jakarta: Dapartemen Pendidikan Nasional.

[2] Muharom, T. (2014). Pengaruh Pembelajaran Dengan Model Kooperatif Tipe Student Teams Achievement Division (Stad) Terhadap Kemampuan Penalaran Dan Komunikasi Matematik Peserta Didik Di SMK Negeri Manonjaya Kabupaten Tasikmalaya. Jurnal Pendidikan dan Keguruan.

[3] Kurniasari, Y., \& Susanah. (2013). Penerapan Teknik Pembelajaran Probing Prompting Untuk Mengetahui Kemampuan Penalaran Matematika Siswa Kelas 7 G Di SMPN 1 Rejoso. Jurnal Matematika UNESA.

[4] Septian, A. (2014). Pengaruh Kemampuan Prasyarat Terhadap Kemampuan Penalaran Matematis Mahasiswa Dalam Matakuliah Analisis Real. Jurnal Kajian Pendidikan.

[5] Usniati, M. (2011). Meningkatkan Kemampuan Penalaran Matematika Melalui Pendekatan Pemecahan Masalah. Jurnal UIN Syarif Hidayatullah.

[6] Santyasa, I. W. (2007). Model-model Pembelajaran Inovatif. Pelatihan tentang Penelitian Tindakan Kelas bagi Guru-Guru SMP dan SMA. Nusa penida.

[7] Firmansyah, Wonorahardjo, S., \& Arief, M. (2016). Penerapan Model Pembelajaran Problem Solving Berbantuan Web Pada Materi Ekstraksi Terhadap Hasil Dan Motivasi Mahasiswa. Jurnal Pendidikan Sains .

[8] Sugiyono. (2008). Metode Penelitian Pendidikan (Pendekatan Kuantitatif, Kualitatif, dan $R \& D)$. Bandung: Alfabeta

[9] Sudijono, A. (2012). Pengantar Evaluasi Pendidikan. Jakarta: PT RajaGrafindo Persada.

[10] Widiyanto, M. A. (2013). Statistika Terapan. Jakarta: PT Elex Media Komputindo. 